\title{
PERAN GANDA HAKIM SEBAGAI MEDIATOR BAGI PENYELESAIAN PERKARA PERDATA DI PENGADILAN TERKAIT KODE ETIK PROFESI
}

\author{
Oleh: \\ Dely Bunga Saravistha
}

\author{
Program Studi, Fakultas Hukum Universitas Mahendradatta \\ Jl. Ken Arok No. 12 , Peguyangan Denpasar Utara, Bali 80115.
}

\author{
(delibunga@gmail.com)
}

\begin{abstract}
Abstrak. Pengintegrasian mediasi melalui Peraturan Mahkamah Agung Nomor 1 Tahun 2016 tentang Prosedur Mediasi Pengadilan (selanjutnya disebut Perma 1 tahun 2016) telah memberikan tugas dan tanggung jawab baru bagi hakim, yang selain menjadi hakim juga dibutuhkan untuk melakukan fungsi mediator. Mediator dan Hakim keduanya profesi hukum, masing-masing yang memiliki Kode Etik dan karakteristik profesional. Penelitian ini merupakan penelitian hukum normatif, penelitian hukum yang meletakkan hukum sebagai sistem norma bangunan dalam bentuk prinsip-prinsip, norma, aturan hukum, keputusan pengadilan, perjanjian dan doktrin ahli. Keberadaan Perma pada tahun 2016 telah membuat hakim memiliki peran ganda yang saling bertentangan. Dampak dari posisi dan peran ganda hakim di pengadilan merupakan akumulasi dari dokumen kasus yang masih terjadi karena jumlah hakim tidak sebanding dengan intensitas kasus yang masuk dan juga karena hakim yang mendominasi proses mediasi peradilan masih sangat jarang untuk melihat keberhasilan. Sehingga keberadaan mediasi hanya terkesan mengulur-ulur Sengketa menetap.
\end{abstract}

Kata kunci: Peran Ganda Hakim, Mediator Yudisial, Kode Etik Profesional

ABSTRACT. The integration of mediation by the Supreme Court Regulation No. 1 of 2016 on Mediation Procedure Court (hereinafter called Perma 1 of 2016) has given new duties and responsibilities of judges, which in addition to being a judge is also required to perform the function of mediator. Mediator and Judge are both legal profession, each of which has a Code of Ethics and professional characteristics. This research is a normative law, the legal research that lay down the law as a system of building norms in the form of principles, norms, rules of law, court decisions, agreements and doctrines of experts. Perma existence in 2016 has made judges have dual roles that are mutually contradictory. The impact of the position and the dual role of judges in the courts is an accumulation of case files still occur because of the number of judges is not proportional to the intensity of incoming cases and also due to judges who dominate the judicial mediation process is still very rare to see success. So that the existence of mediation only be impressed stalling settling disputes.

Keywords: Dual Role of Judges, Judicial Mediator, Code of Professional Ethics 


\section{Pendahuluan}

\subsection{Latar Belakang}

Hakim sebagai subsistem di lembaga peradilan merupakan pelaku inti yang seharusnya secara fungsional melaksanakan tugas kekuasaan kehakiman. Hakikat kekuasaan kehakiman memiliki pilar yang terdiri dari badan peradilan yang ditegakkan sesuai hukum positif, aparatur penegak hukum yaitu hakim itu sendiri, panitera, juru sita, dan tenaga non hakim lainnya dan sarana hukum baik hukum materiil maupun formil (acara).

Dalam melaksanakan tugasnya sebagai hakim, maka haruslah dipahami mengenai ruang lingkup tugas dan kewajiban hakim dalam pengaturan hukum positif di Indonesia. Sehingga seorang hakim akan mampu bersikap lebih profesional dalam menjalankan profesi sekaligus mata pencahariannya sebagai hakim dengan tetap melaksanakan ketentuan yang diamanatkan juga dalam Kode Etik Profesi Hakim.

Dalam hukum positif mengenai kekuasaan kehakiman di Indonesia yaitu Undang-Undang Nomor 48 Tahun 2009 tentang Kekuasaan Kehakiman Pasal 1 butir (5) dan (7) diatur mengenai ruang lingkup hakim, yaitu Mahkamah Agung dan hakim pada badan peradilan yang berada di bawahnya baik di peradilan umum, peradilan agama, peradilan militer, peradilan tata usaha negara dan hakim-hakim di lingkungan peradilan khusus yang berada di

15 Wildan Suyuti, 2013, Kode Etik Hakim, Kencana Group, Jakarta, hlm. 105

16 Rachmadi Usman, 2012, Mediasi di Pengadilan dalam Teori dan Praktik, Sinar Grafika, Jakarta, h. 27 lingkungan peradilan yang sama, serta hakim di Mahkamah Konstitusi. ${ }^{15}$

Perkara yang menjadi kewenangan di pengadilan negeri pada pokoknya ada dua yaitu perkara pidana dan perdata. Hakim yang berada di lingkungan peradilan tersebutlah yang menangani penyelesaian atas kedua jenis perkara tersebut. Hal ini disebabkan karena hakikat tugas pokok hakim adalah menerima, memeriksa, mengadili, memutuskan, dan menyelesaikan setiap perkara yang diajukan ke pengadilan.

Khususnya dalam hal penyelesaian perkara perdata di pengadilan. Sejak pengintegrasian mediasi ke dalam sistem acara perdata di pengadilan melalui Peraturan Mahkamah Agung Nomor 1 Tahun 2016 tentang Prosedur Mediasi di Pengadilan (selanjutnya disebut Perma 1/2016), tugas dan fungsi hakim menjadi bertambah. Bahkan, tidak hanya menjadi tugas hakim di lingkungan pengadilan tingkat pertama saja. Mediasi yang dikenal dengan mediasi yudisial ini juga dapat diajukan di tingkat banding, kasasi, bahkan sampai ke peninjauan kembali. ${ }^{16}$

Tujuan dari pengintegrasian ini adalah untuk mengurangi penumpukan berkas perkara di pengadilan. Namun, pada kenyataannya proses mediasi yudisial menyebabkan tugas hakim bertambah karena didominasi oleh penggunaan mediator hakim. ${ }^{17}$ Padahal di lingkungan peradilan juga

17 Syahrizal Abbas, 2009, Mediasi dalam Perspektif Hukum Syariah, Hukum Adat, dan Hukum Nasional, Kencana Prenada Media Group, Jakarta, h. 312. 
tersedia mediator dari kalangan non hakim, yang telah memiliki sertifikat mediator. Kepemilikan sertifikat tersebut menunjukkan kelayakan dalam menjalankan fungsi sebagai mediator.

\begin{tabular}{lcr}
\multicolumn{2}{c}{ Keberadaan Perma 2016} \\
bertujuan untuk & mengurangi \\
penumpukan & berkas perkara di \\
pengadilan. & Sehingga proses
\end{tabular}
penyelesaiannya dapat mewujudkan Asas Tri Logi Peradilan yaitu Sederhana, Cepat dan Biaya Ringan. Efektif atau tidaknya implementasi dari Perma 1/2016 ini, akan dianalisis melalui struktur hukum, substansi hukumnya, sarana dan prasarana dan budaya hukum.

\subsection{Rumusan Masalah}

Hal ini menarik untuk diteliti dan dianilisis lebih lanjut berdasarkan uraian latar belakang yang telah dikemukakan diatas, maka diangkat dua permasalahan yaitu:

1. Bagaimana pengaturan dalam substansi Perma 2016 yang mengenai tugas dan fungsi hakim sebagai mediator yang terindikasi menyebabkan peran ganda hakim?

2. Bagaimanakah dampak keberadaan Perma 1/2016 terhadap tugas dan fungsi hakim dalam Undang-Undang Nomor 48 Tahun 2009 tentang Kekuasaan Kehakiman terkait Kode Etik Profesi?

\subsection{Tujuan Penulisan}

1. Untuk mengetahui dan menganalisis pengaturan dalam Perma 1/2016 mengenai tugas dan fungsi hakim sebagai mediator yang terindikasi menjadi penyebab peran ganda hakim.

18 Mukti Fajar ND dan Yulianto Achmad, MH., 2013, Dualisme Penelitian Hukum Normatif
2. Untuk mengetahui dan menganalisis secara lebih mendalam mengenai dampak keberadaan Perma 1/2016 terhadap tugas dan fungsi hakim dalam hukum positif yang mengatur tentang Kekuasaan Kehakiman terkait Kode Etik Profesi.

\section{METODE PENELITIAN}

\subsection{Jenis Penelitian}

Penulisan jurnal ini menggunakan metode penelitian normatif. Dimana yang dimaksud dengan penelitian jenis ini adalah yang menempatkan hukum sebagai sebuah bangunan sistem norma baik itu asas, norma, kaidah hukum, putusan, pengadilan, perjanjian serta doktrin para ahli hukum.

Peter Mahmud memberikan definisi terhadap penelitian normatif sebagai penelitian yang bertujuan menemukan aturan hukum, prinsipprinsip hukum, maupun doktrin hukum guna memecahkan permasalahan hukum yang ada. Hasil dari proses penelitian ini adalah berupa argumentasi, teori atau konsep baru sebagai suatu preskripsi untuk pemecahan suatu masalah. ${ }^{18}$

\subsection{Jenis Pendekatan}

Dalam penelitian, digunakan beberapa jenis pendekatan, antara lain:

1. Pendekatan Fakta atau The Fact Approach, yaitu dengan melihat pada kenyataan yang terjadi setelah keberadaan Perma 1/2016 yang menyebabkan perubahan tugas dan fungsi hakim dalam penyelesaian perkara di pengadilan.

2. Pendekatan Perbandingan atau Comparative Approach, yaitu dengan jalan membandingkan tentang tugas dan fungsi hakim

dan Empiris, Pustaka Pelajar, Yogyakarta, h. 34 
dalam menjalankan amanat Kekuasaan Kehakiman dan juga menjalankan Kode Etik Profesinya sebelum keberadaan Perma 1/2016 dengan keadaan setelah keberadaan Perma $1 / 2016$, dimana sebagai seorang mediator hakim juga wajib mentaati Kode Etik Profesi Mediator.

\section{Hasil dan Pembahasan}

3.1 Tinjauan Umum tentang Peran Ganda Hakim, Mediator dan Kode Etik Profesi

Dalam ketentuan Pasal 1 Angka (5) Undang-Undang Nomor 48 Tahun 2009 tentang Kekuasaan Kehakiman diberikan definisi tentang hakim. Hakim adalah hakim pada Mahkamah Agung dan hakim pada badan peradilan yang berada di bawahnya dalam lingkungan peradilan umum, peradilan agama, peradilan militer, lingkungan peradilan tata usaha negara dan hakim pada peradilan khusus yang berada dalam lingkungan peradilan tersebut.

Tugas pokok daripada pengadilan sebagai penyelenggara Kekuasaan Kehakiman adalah menerima, memeriksa da mengadili serta menyelesaikan setiap perkara yang diajukan kepadanya. ${ }^{19}$ Di dalam banyak literatur dinyatakan bahwa tugas pokok daripada hakim adalah menerima, memeriksa dan mengadili serta menyelesaikan setiap perkara yang ditujukan padanya. Dari sini terlihat bahwa tugas peradilan sama dengan hakim karena kedua hal ini tidak mungkin dipisahkan. ${ }^{20}$

Dalam Pasal 1 Ayat (6) Perma 1/2016 ditentukan mengenai definisi

19 Mustofa Wildan Suyuti, 2013, Kode Etik Hakim, Kencana, Jakarta, h. 55 Yogyakarta, Liberty Yogyakarta, h. 117. mediator, yaitu pihak netral yang membantu para pihak dalam proses perundingan guna mencari berbagai kemungkinan penyelesaian sengketa tanpa menggunakan cara memutus atau memaksa sebuah penyelesaian. Mediator hakim adalah hakim yang dipilih oleh para pihak (Pasal 8 Perma 1/2016) atau yang ditunjuk oleh Ketua Majelis Hakim untuk menjalankan fungsi mediator dan merupakan seorang Sarjana Hukum (Pasal 11 Ayat (5) dan (6) Perma 1/2016).

Tugas dari mediator hakim tidak lain adalah menangani penyelesaian sengketa perdata yang masuk ke pengadilan negeri atau pengadilan tingkat pertama secara damai (Pasal 4 Perma 1/2016) dengan atau tanpa memiliki sertifikat mediator. Namun, hal yang menarik dari mediator hakim dan banyak disoroti dan dikritisi adalah tugas lain dari mediator hakim dalam kapasitasnya sebagai hakim, yaitu memberikan penyelesaian secara ajudikasi. Sehingga sejak pengintegrasian Perma 1/2016 telah terjadi kondisi yang membuat hakim memiliki peran yang ganda. Peran ganda ini menjadi indikasi berkurangnya kepercayaan publik terhadap konsep fundamental sistem peradilan. ${ }^{21}$

Kode etik profesi adalah kompas yang akan menunjukkan arah bagi suatu profesi dan sekaligus menjamin mutu moral individu profesi itu di mata masyarakat. Dalam konteks profesi, kode etik memiliki karakteristik antara lain: ${ }^{22}$

a. merupakan produk etika terapan Karena dihasilkan berdasarkan penerapan

\footnotetext{
21 A. Syukur Fatahillah, Mediasi Yudisial Di Indonesia, Op. Cit., h. 39

22 Sumaryono, 2012, Etika Profesi Hukum: Norma-Norma Bagi Penegak Hukum, Kanisius, Yogyakarta, h. 147.
} 
pemikiran etis atas suatu profesi tertentu;

b. dapat berubah ataupun diubah seiring dengan perkembangan jaman seperti adanya kemajuan ilmu pengetahuan dan tegnologi. Dampak negatifnya adalah sering kali menimbulkan penyalahgunaan yang meresahkan masyarakat dan membingungkan profesi itu sendiri;

c. tidak akan berlaku efektif bila keberadaanya hanya diletakkan begitu saja dari atas (yaitu pemerintah atau instansi lain) sebab tidak akan dijiwai oleh cita-cita dan nilai-nilai yang hidup dalam kalangan itu sendiri;

d. merupakan hasil dari selfregulation atau pengaturan diri dari internal kalangan profesi itu sendiri. Ini bertujuan untuk mewujudkan nilai-nilai moral yang dianggap paling fundamental, yang penerapannya tidak dapat dipaksakan dari luar;

e. tujuan utama keberadaannya adalah untuk mencegah terjadinya perilaku yang tidak etis dari kalangan profesi itu sendiri. Ini adalah alasan adanya ketentuan wajib lapor tentang pelanggarannya.

Dalam Kode Etik Hakim atau Kode Kehormatan Hakim, seorang pengemban profesi ini dituntut untuk memiliki sifat-sifat tertentu, salah satu yang terpenting adalah

23 Pengayoman Hakim yaitu tentang: Kode Kehormatan Hakim atau Kode Etik Hakim. mampu memutus berdasarkan hati nurani. ${ }^{23}$ Namun seperti telah diungkapkan sebelumnya bahwa keberadaan Perma 1/2016 telah membuat hakim berhadapan dengan dua Kode Etik sekaligus. Sehingga sangat sulit ketika seseorang harus tunduk dan mentaati dua kode etik sekaligus. Apalagi sifat dari kedua peranan itu sangat bertolak belakang.

\subsection{Tugas dan Fungsi Hakim Sebagai Mediator Dalam Perma 1/2016 yang Menyebabkan Terjadinya Peran Ganda}

Sebelum perkara perdata diselesaikan secara litigasi melalui proses persidangan. Maka wajib terlebih dahulu melalui proses mediasi yudisial agar tidak menyebabkan putusan menjadi batal demi hukum. Mediasi yudisial dilakukan oleh mediator yudisial yang terdiri dari semua kalangan hakim dan dari luar kalangan hakim.

Tugas dan fungsi hakim dalam Perma 1/2016 adalah menangani penyelesaian sengketa perdata yang masuk ke pengadilan negeri atau pengadilan tingkat pertama (Pasal 4 Perma 1/2016) dengan atau tanpa memiliki sertifikat mediator. Jadi kepemilikan sertifikat hanya menjadi syarat mutlak yang hanya diharuskan bagi mediator non hakim saja. ${ }^{24}$

Tugas dan fungsi hakim sebelum keberadaan Perma 1/2016 adalah yang diamanatkan dalam Undang-Undang Nomor 48 Tahun 2009 tentang Kekuasaan Kehakiman, antara lain:

a. Menjalankan peradilan dengan menjunjung tinggi asas penyelenggaraan peradilan yaitu Demi Keadilan yang Berketuhanan Yang Maha Esa, Pancasila, selalu 
dilandasai atas undang-undang, Asas Tri Logi Peradilan (Pasal 2).

b. Menjaga kemandirian peradilan (Pasal 3).

c. Mengadili dengan tidak membedakan orang dan selalu membantu para justiabellen mengatasi segala rintangan dan hambatan untuk mewujudkan asas Tri Logi Peradilan (Pasal 4).

d. Menggali, mengikuti, dan memahami nilai-nilai hukum dan rasa keadilan yang hidup dalam masyarakat (pasal 5 Ayat (1). Dalam UUKK Nomor 4 Tahun 2004 mengadili menurut hukum dan tidak membeda-bedakan orang (pasal 5 ayat (1) UU no.4/2004)

e. Dalam mempertimbangkan berat ringannya pidana, hakim wajib memperhatikan sifat yang baik dan yang jahat dari terdakwa (pasal 8 ayat (2).

f. Dilarang menolak atau wajib memeriksa, mengadili, dan memutus perkara yang diajukan dengan alasan hukumnya tidak ada atau kurang jelas (Pasal 10 Ayat (1)) dan mengusahakan penyelesaian perkara perdata secara damai (Pasal 10 Ayat (2)).

g. Menyertakan pertimbangan dan pendapatnya secara tertulis dalam setiap putusan pengadilan dan setiap perbedaan pandangan wajib dimuat dalam putusan (Pasal 14 Ayat (2) dan (3)).

h. Mengundurkan diri dari persidangan apabila mempunyai hubungan keluarga sampai derajat ketiga atau hubungan suami istri meskipun telah bercerai dengan ketua,salah seorang hakim anggota, jaksa, advokat, atau panitera (pasal 17 Ayat (3)).

i. Mengundurkan diri dari persidangan apabila mempunyai hubungan keluarga sedarah atau semenda sampai derajat ketiga dan hubungan suami atau istri meskipun telah bercerai dengan yang diadili atau advokat (pasal 17 Ayat (4)).

j. Mundur dengan inisiatif sendiri dari persidangan apabila mempunyai kepentingan langsung atau tidak langsung dengan perkara yang dipersidangkan (pasal 17 Ayat (5)).

k. Sebelum memangku jabatannya hakim wajib melakukan sumpah jabatannya (pasal 30 ayat (1) UU No.4/2004)

1. Memiliki integritas dan kepribadian yang tidak tercela,jujur,adil.profesional,dan berpengalaman di bidang hukum (pasal 31 UU No.4/2004)

$\mathrm{m}$. Mengedepankan atau menjunjung tinggi kemandirian peradilan (pasal 32 UU No.4/2004)

n. Mampu memberikan suatu pertimbangan atau pendapat tertulis terhadap perkara yang sedang diperiksa dan menjadi bagian yang tak terpisahkan dari putusan.(pasal 19 UU ayat (4) UU No.4/2004)

o. Tidak diperkenankan melakukan penolakan terhadap perkara (pasal 16 ayat (1) UU No.4/2004)

Dalam kapasitasnya sebagai seorang mediator, hakim sama sekali harus mengabaikan penerapan hukum positif. Mediasi adalah penyelesaian yang bertujuan untuk memberikan hasil akhir yang win-win solution. Seorang mediator bukanlah seorang hakim yang dapat memutuskan perkara 
berdasarkan pada fakta-fakta hukum. ${ }^{25}$

\subsection{Dampak keberadaan Perma 1/2016 terhadap tugas dan fungsi hakim dalam Undang-Undang Nomor 48 Tahun 2009}

Sejak pengintegrasian mediasi melalui Perma 1/2016, hakim yang awalnya hanya fokus pada penyelesaian perkara baik perdata maupun pidana secara adjudikasi atau memutus, memiliki kewajiban lain yaitu menjalankan fungsi mediator. Kedua peran tersebut karakteristiknya sangat bertentangan satu sama lain, sedangkan Perma 1/2016 tidak mewajibkan hakim untuk mendapatkan semacam pelatihan mediator terlebih dahulu. Tugas dan fungsi dari mediator, antara lain: ${ }^{26}$

a. Mempersiapkan usulan jadwal pertemuan mediasi bagi para pihak untuk dibahas dan disepakati (Pasal 15 Ayat (1) Perma 1/2016);

b. Mendorong para pihak untuk berperan langsung/aktif dalam proses mediasi (Pasal 15 Ayat (2) Perma 1/2016);

d. Melakukan kaukus, apabila dianggap perlu (Pasal 15 Ayat (3) Perma 1/2016);

e. Mediator wajib mendorong para pihak untuk menelusuri dan menggali kepentingan mereka dan mencari berbagai pilihan penyelesaian sengketa yang terbaik bagi para pihak (Pasal 15 Ayat (4) Perma 1/2016).

f. Wajib mentaati pedoman perilaku mediator yang ditetapkan oleh Mahkamah Agung atau disebut Kode Etik Mediator (Pasal 24 Ayat (1) dan (2) Perma 1/2016).

25 John Michael Haynes, Gretchen L. Haynes dan Larry Sun Fong, 2004, Mediation: Postive Conflict Management, New York: Suny Press, h. 5 .
Selain itu dalam proses mediasi terdapat kaukus, yaitu pertemuan sepihak antara mediator dengan salah satu pihak tanpa dihadiri oleh pihak lainnya. ${ }^{27}$ Dalam proses ini hakim sebagai mediator wajib melakukan penggalian terhadap hal-hal yang sebelumnya sulit diungkapkan, biasanya hal ini karena terkait masalah harga diri dan gengsi. Apalagi bagi pihak yang merasa nama baiknya sudah dicemari melalui adanya gugatan oleh pihak satunya lagi.

Dalam proses mediasi seorang mediator akan memberikan rekomendasi kepada para pihak untuk mengarahkan para pihak pada sebuah kesepakatan damai. Walaupun keputusan mengenai dapat diterima atau tidaknya rekomendasi itu tetap berada di tangan para pihak. Hal ini bertentangan dengan Kode Etik Hakim dan Prinsip-Prinsip Bangalore tentang Perilaku Hakim 2002, khususnya tentang kemandirian, ketidakberpihakan dan integritas hakim.

$$
\text { Landasan yuridis yang }
$$
memberikan jaminan terhadap eksistensi mediator yudisial non hakim dalam ketentuan Perma 1/2016, hanya rumusan mati saja. Penyebab lain ketiadaan penggunaan mediator yudisial non hakim dalam proses mediasi di pengadilan, antara lain disebabkan:

a. Mediator non hakim berbayar, artinya untuk menggunakan jasanya para pihak dibebankan biaya tambahan;

b. Tidak ada keinginan dari MA untuk memberikan ruang pengadilan untuk mediasi secara gratis sama seperti penggunaan jasa mediator

26 Wildan Suyuthi Mustofa, 2013, Kode Etik Hakim, Kencana, Jakarta, h. 55.

27 A. Syukur Fatahillah, 2012, Mediasi Yudisial Di Indonesia, CV. Mandar Maju, Bandung, h. 39. 
hakim kepada mediator non hakim;

c. Adanya persepsi bahwa ruang pengadilan bukan untuk orang luar;

d. Kekhawatiran berkompetensi dengan mediator non hakim untuk mencapai keberhasilan mediasi.

Kondisi diatas, juga akan ditinjau dari Teori Efektifitas Hukum dari Soerjono Soekanto, yang terdiri dari: ${ }^{28}$

a. Struktur hukum;

Terlihat bahwa keberadaan Perma 2016 telah memberikan hakim tugas dan fungsi yang melahirkan kewajiban baru bagi hakim, khususnya dalam menyelesaikan perkara perdata di pengadilan. Sehingga hakim tidak hanya bertugas menerima, memeriksa dan memutus perkara yang masuk ke pengadilan saja, melainkan juga bertugas menjalankan fungsi sebagai mediator yudisial. Hal ini menimbulkan hambatan karena jumlah hakim di pengadilan sangat terbatas jumlahnya.

Keberadaan mediator non hakim di pengadilan hanya sekedar pajangan saja dan landasan yuridis keberadaan mediator non hakim dalam Perma 2016 hanya menjadi rumusan mati belaka. Dalam proses mediasi yudisial tidak satupun perkara yang menggunakan jasa mediator ini. Sehingga menyebabkan hakim yang jumlahnya memang sudah sangat terbatas harus menjalankan fungsi tambahan yaitu memediasi. Hal ini berakibat adanya anggapan bahwa penyelesaian perkara perdata mengalami penundaan secara tidak efektif selama 40 hari kerja, apalagi intensitas keberhasilan mediasi sangat amat jarang. Bahkan, dalam satu lingkungan

28 Salim dan Erlies Septiana Nurbani, 2014, Buku Kedua: Penerapan Teori Hukum Pada pengadilan tidak pernah mencatat sama sekali mengenai adanya keberhasilan mediasi di lingkungannya. ${ }^{29}$

b. Substansi hukum;

Bahwa Perma 1/2016 seharusnya mengatur lebih jelas dan terperinci mengenai pembebanan tugas bagi hakim menjalankan fungsi mediator. Hakim pemeriksa perkara yang sama sebaiknya tidak boleh melakukan mediasi terhadap kasus yang sama karena dapat mengancam kemandirian, ketidakberpihakan dan integritas hakim di mata masyarakat pencari keadilan.

c. Sarana dan Prasarana;

Mahkamah Agung sebagai pihak yang mengeluarkan produk hukum berupa perma, dirasa belum optimal dalam mengupayakan ruang mediasi yang layak di tiap-tiap pengadilan. Sehingga dapat menyebabkan pelaksanaan proses mediasi menjadi kurang efektif karena adanya rasa tidak nyaman dan kurang menjamin privasi para pihak pada saat proses berlangsung. Selain itu, Mahkamah Agung juga seharusnya merealisasikan insentif bagi hakim yang berhasil menjalankan fungsi mediator, sehingga mampu meningkatkan motivasi hakim untuk benar-benar menyukseskan bersama implementasi Perma 2016.

d. Budaya Hukum;

Budaya hukum masyarakat, khususnya para pencari keadilan terlihat masih kurang memahami tujuan dan makna keberadaan mediasi yudisial. Selain itu mereka menganggap mediasi yudisial hanya mengulur-ulur waktu penyelesaian karena sebelum gugatan diajukan salah satu pihak khususnya penggugat sudah pernah mengupayakan penyelesaian secara kekeluargaan dengan tergugat di luar pengadilan.

Penelitian Disertasi dan Tesis, Rajawali Pers, Jakarta, h. 130.

29 A. Syukur Fatahillah, Op. Cit., h. 48. 
Tidak adanya reaksi atau tanggapan seperti yang diharapkanlah, yang kemudian menyebabkan gugatan diajukan. Walaupun litigasi dirasa sangat kaku, namun paling tidak dirasa lebih mampu memberikan suatu kepastian hukum bagi pihak yang ingin mendapatkan keadilan. ${ }^{30}$ Hal ini ditunjukkan dengan intensitas ketidakhadiran para pihak yang disengaja dalam proses mediasi. Ketidakhadiran ini berakibat gagalnya mediasi tersebut, sehingga perkara akan dilanjutkan ke proses persidangan. Kemudian ditinjau dari budaya hukum penegak hukumnya yaitu mediator hakim yang selama ini mendominasi seluruh mediasi perkara perdata di pengadilan, tampak kurang bersemangat untuk ikut menyukseskan implementasi Perma 2016. Hal ini tidak dapat disalahkan, karena insentif dan jenjang karier yang dijanjikan oleh Mahkamah Agung untuk hakim, seperti yang tertulis dalam ketentuan Pasal 25 Perma 1/2016 bagi hakim yang berhasil menjalankan fungsi mediator, belum dapat terealisasikan.

\section{PENUTUP}

\subsection{Kesimpulan}

Dari pembahasan di atas dapatlah ditarik suatu kesimpulan, yaitu :

a. Berdasarkan penelusuran yang dilakukan, mengenai tugas dan fungsi hakim setelah pengintegrasian mediasi melalui Perma 1/2016 telah memberikan hakim tugas dan fungsi baru yang mengakibatkan bertambahnya kewajiban yang harus dipikul oleh hakim. Selain itu hakim yang tunduk pada Kode Etik Profesi Hakim juga wajib tunduk pada Kode Etik Mediator. b. Akibat dari kedudukan dan peran ganda hakim di pengadilan adalah penumpukan berkas perkara tetap saja terjadi karena jumlah hakim tidak sebanding dengan intensitas perkara yang masuk dan juga disebabkan karena hakim yang mendominasi proses mediasi yudisial masih sangat jarang menemui keberhasilan. Sehingga keberadaan mediasi hanya menjadi terkesan mengulur-ulur waktu penyelesaian perkara.

\subsection{Saran}

1. Agar Mahkamah Agung mengatur lebih jelas mengenai keterlibatan hakim dalam proses mediasi dengan mempertimbangkan konsekuensinya bagi hakim yang telah memiliki Kode Etik tersendiri, sehingga tidak ada persepsi yang membingungkan di kalangan masyarakat tentang profesi hakim yang menyandang dua profesi yaitu hakim dan mediator yang sama-sama memiliki Kode Etik Profesi masing-masing.

2. Sangat penting agar Mahkamah Agung lebih memperhatikan dampak dari substansi Perma 1/2016 yang melibatkan hakim, khususnya hakim pemeriksa pokok perkara yang sama dalam proses mediasi yudisial. Hal ini dapat mengancam kemandirian, ketidakberpihakan dan integritas hakim sehingga kepercayaan masyarakat kepada Lembaga Peradilan akan terancam. Selain itu, agar implementasi Perma 1/2016 benar-benar dapat mencapai tujuannya dalam mengurangi penumpukan berkas perkara. 


\section{DAFTAR PUSTAKA}

\section{Buku:}

A. Syukur Fatahillah, 2012, Mediasi Yudisial Di Indonesia, CV. Mandar Maju, Bandung

John Michael Haynes, Gretchen L. Haynes dan Larry Sun Fong, 2004, Mediation: Postive Conflict Management, New York: Suny Press

Mustofa Wildan Suyuti, 2013, Kode Etik Hakim, Kencana, Jakarta

Rachmadi Usman, 2012, Mediasi di Pengadilan dalam Teori dan Praktik, Penerbit Sinar Grafika, Jakarta

Salim dan Erlies Septiana Nurbani, 2014, Buku Kedua: Penerapan Teori Hukum Pada Penelitian Disertasi dan Tesis, Rajawali Pers, Jakarta
Soedikno Mertokusumo, 2009, Hukum Acara Perdata Indonesia (Edisi kedelapan), Yogyakarta, Liberty Yogyakarta

Sumaryono, 2012, Etika Profesi Hukum: Norma-Norma Bagi Penegak Hukum, Kanisius, Yogyakarta

Syahrizal Abbas, 2009, Mediasi dalam Perspektif Hukum Syariah, Hukum Adat, dan Hukum Nasional, Kencana Prenada Media Group, Jakarta

Wildan Suyuti, 2013, Kode Etik Hakim, Kencana Group, Jakarta

\section{Perundang-undangan:}

Undang-Undang Nomor 48 Tahun 2009 tentang Kekuasaan Kehakiman

Peraturan Mahkamah Agung Nomor 1 Tahun 2016 tentang Prosedur Mediasi di Pengadilan 